\title{
Antalya İli Su Ürünleri Tüketim Alışkanlıklarının Belirlenmesi*
}

\author{
Merve ARSLAN ${ }^{1 * *}$, Levent IZC $^{2}$
}

${ }^{1}$ Süleyman Demirel Üniversitesi, Fen Bilimleri Enstitüsü, Isparta

${ }^{2}$ Süleyman Demirel Üniversitesi, Eğirdir Su Ürünleri Fakültesi, Isparta

$$
\begin{array}{rr}
\text { Geliş : } & 22.01 .2016 \\
\text { Kabul : } & 21.04 .2016
\end{array}
$$

**:Sorumlu Yazar: arslanmerve12@gmail.com

Basıl1 ISSN: 1300 - 4891E. Dergi ISSN: 1308 - 7517

\section{Özet}

Bu araştırmada, Antalya ili su ürünleri tüketim alışkanlıklarının belirlenmesi amaçlanmıştır. Eylül 2014 Ağustos 2015 tarihleri arasında yapılan çalışmada, önceden belirlenen sorular, tesadüfi olarak belirlenen bireylere soru-cevap şeklinde uygulanmıştır. Anket, tesadüfi olarak seçilen 663'ü kadın ve 702'si erkek olmak üzere 1365 bireye uygulanmıştır. Ankete katılan bireyler arasında 31-40 $(\% 29,15)$ yaş grubu en fazla oranda tespit edilmiştir. Araştırmaya katılan bireylerin meslek grupları içerisinde $\% 25,42$ en fazla oranla serbest meslekle uğraştıklarını belirtmişlerdir. Katılımcıların \%34,72'sinin üniversite, \%31,72'sinin ilkokul, $\% 23,08$ 'inin lise ve \%10,48'inin ortaokul mezunu olduğu saptanmıştır. Katılımcıların \%43,67'sinin iki haftada bir gün su ürünleri tükettiği ve \%80,0'ninin taze ürünleri tercih ettiği görülmüştür. Ankete katılan bireylerin $\% 46,96$ 's1 ekonomik ve pratik olduğu için tavuğu tercih ettiklerini belirtmişlerdir. Bunu \%36,12'lik bir oranla kırmızı et ve \%16,92 ile balık eti izlemiştir. Araştırmamızda su ürünleri tüketimini olumsuz etkileyen faktörlerin başında tüketim alışkanlığının olmaması $(\% 43,45)$ katılımcılar tarafından belirtilmiştir.

Anahtar kelimeler: Su ürünleri, Tüketim alışkanlığı, Anket, Antalya

\section{The Determination Of Habit Of Seafood Consumption Of The Antalya Province}

\begin{abstract}
:
In this research, it was aimed to determine habits of seafood consumption in the Antalya province. In the research between September 2014-August 2015, predetermined questions were applied to randomly determined people as question-answer. The survey was applied to totally 1365 randomly selected people, 663 women and 702 men. People who took the survey were mostly in the age range of 31-40 (29.15\%). 25.42\% of the participants of survey were self-employed between all occupational groups. $34.72 \%$ of the participants were graduated from a university, $31.72 \%$ of the participants were graduated from a primary school, $23.08 \%$ of the participants were graduated from a high school and $10.48 \%$ of the participants were graduated from secondary school. $43.67 \%$ of the participants consumed a seafood 1 day in 2 weeks and $80 \%$ of them preferred fresh seafood. $46.96 \%$ of the participants stated that they prefer chicken meat because of economic and pratic and $36.12 \%$ meat and $16.92 \%$ fish meat. In the research it was stated by the participants that the first factor affecting seafood consumption negatively was the lack of consumption habit (43.45\%).
\end{abstract}

Keywords: Seafood, Habit of Consumption, Survey, Antalya

*Bu çalışma, yüksek lisans tezinden özetlenmiştir.

\section{GİRIŞ}

Dünya nüfusunun artmasıyla birlikte toplumların karşılaştıkları en önemli sorunlardan biri dengeli ve yeterli beslenmedir. Su ürünleri gerek besinsel kalitesi gerekse de sindiriminin kolay olması bakımından her yaş grubuna hitap eden önemli besin kaynakları içerisinde yer almaktadır. Su ürünlerinin taze ve işlenmiş olarak tüketiminin alışkanlık haline getirilerek artırılması bu açıdan önemlidir. 
Su ürünlerinin insan beslenmesindeki yeri oldukça eski yıllara dayanmaktadır. Son yıllarda yapılan çalışmalarla su ürünlerinin önemi daha anlaşılır olmuştur. Dünyada karşılaşılan ölümlerin başında kalp damar hastalıkları, kolestrol ve şeker gelmektedir. Balık etinin etkileri yıllardır araştırılmış ve olumlu sonuçlar elde edilmiştir. Dekosaheksaenoik asit (DHA) ve Eikosapentaenoik asit (EPA) su ürünleri etlerinde bulunan iki önemli yağ asididir. Bu yağ asitlerinin insan sağlı̆̆ açısından önemli biyokimyasal ve fizyolojik işlevleri olduğu belirtilmektedir (Turan vd., 2006). Su ürünleri etleri doğada çok rastlanan aminoasitleri bulundurmalarının yanında valin, lösin, izolösin, lizin, treonin, sistin, sistein, metionin, fenilalanin gibi esansiyel karakterdeki aminoasitleri de bünyelerinde bulundururlar (Gülyavuz ve Ünlüsayın, 1999). Su ürünleri mineral maddelerce zengin kaynaklardır (Atar ve Alçiçek, 2009). Su ürünlerinde vitamin düzeyi balık türüne göre değişmekle birlikte suda çözünen $\mathrm{B}$ ve $\mathrm{C}$ vitaminleri karasal hayvanlarla benzer olup yağda eriyen $\mathrm{A}, \mathrm{D}, \mathrm{E}$ ve $\mathrm{K}$ vitaminlerini genellikle daha fazla içerirler. (Turan vd., 2006).

Orhan ve Yüksel (2010) Burdur ilinde, Olgunoğlu vd. (2014) Adıyaman ilinde, Hatırlı vd. (2004) Isparta ilinde, Adıgüzel vd. (2009) Tokat ili Almus ilçesinde, Erdal ve Esengün (2008) Tokat ilinde, Şen vd. (2008) Elazı̆̆ ilinde, Çolakoğlu vd. (2006) Çanakkale ilinde, Aydın ve Karadurmuş (2013) Trabzon ve Giresun illerinde, Yüksel vd. (2011) Tunceli ilinde ve Balık vd. (2013) Ordu ilinin Fatsa ve Aybastı ilçelerinde su ürünlerinin tüketimine ilişkin anket çalışması yapmışlardır.

Su ürünleri tüketiminin günümüzde sağlık açısından önemli olduğu bilinmektedir. Ayrıca su ürünleri tüketim alışkanlıklarının belirlenmesi gerek il gerekse ülke düzeyinde sektörel anlamda olumlu katkılar sağlaması bakımından önem taşımaktadır.

$\mathrm{Bu}$ çalışmada, tesadüfi örnekleme ile katılımcılara birebir soru-cevap biçiminde anket yapılarak Antalya ili su ürünleri tüketim alışkanlıklarının belirlenmesi amaçlanmıştır.

\section{MATERYAL ve YÖNTEM}

$\mathrm{Bu}$ çalışmada, Antalya ilinde yaşayanların su ürünleri tüketim alışkanlıklarının belirlenmesi amacıyla Eylül 2014-Ağustos 2015 tarihleri arasında bir yıllık süreyi kapsayan bir anket araştırması yapılmıştır. Anket, tesadüfi olarak seçilen 663'ü kadın ve 702'si erkek olmak üzere toplam 1365 bireye uygulanmıştır. Anket, katılan bireylere birebir soru-cevap şeklinde uygulanarak gerçekleştirilmiştir.

\section{BULGULAR}

Ankete katılan bireylerin \%48,57'si kadın ve \%51,43'ü erkek olarak tespit edilmiştir (Şekil 1).
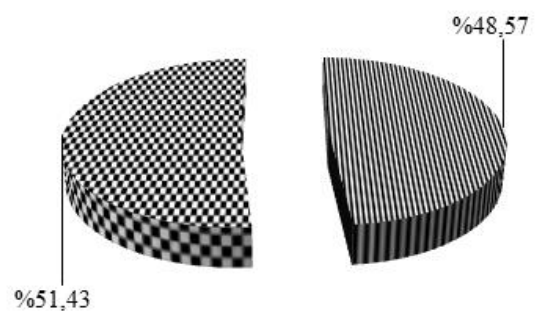

III KADIN

$\triangle$ ERKEK

Şekil 1. Katılımcıların cinsiyet dağılımları 
Yaş grupları, 21-30, 31-40, 41-50, 51-60, 61-70 ve 71-80 olarak belirlenmiştir. Ankete katılan bireylerin yaş dağılımlarına bakıldığında katılımonın en fazla olduğu yaş grubunun 31-40 yaş grubu olduğu tespit edilmiştir. Bunu \%24,54 ile 41-50 yaş grubu izlemiştir. En az katılımcının olduğu yaş grubu ise 71-80 yaş grubu olarak saptanmıştır (Şekil 2).

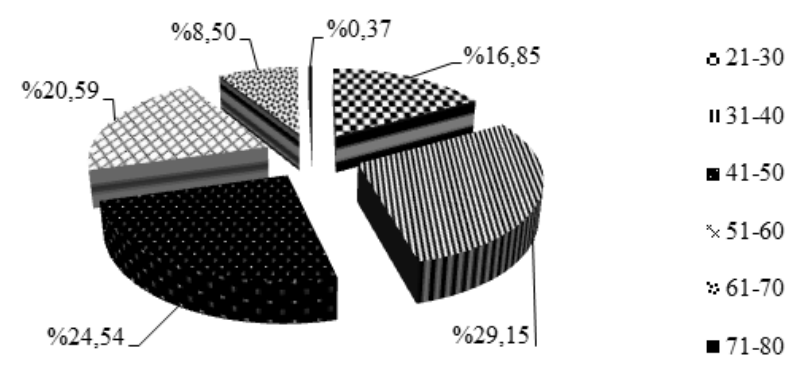

Şekil 2. Katılımcıların yaş dağılımları

Yaş grubu ve cinsiyete göre tüketimde tercih edilen su ürünlerine bakıldığında erkeklerin her yaş grubunda tükettiği su ürünleri hamsi ve çipura olarak belirlenmiştir. Karagöz (31-40 yaş grubu), lahos (31-40 yaş grubu), orkinos (31-40 yaş grubu), mırmır (41-50 yaş grubu), sardalya (41-50 yaş grubu), lokum balığı (31-40 yaş grubu), sazan (2130 yaş grubu) ise sadece tek bir yaş grubunda tüketildiği saptanmıştır. Kadınlarda ise her yaş grubunda tüketilen su ürünleri palamut ve istavrit olmuştur. Mercan (41-50 yaş grubu), çinekop (31-40 yaş grubu), siraz (41-50 yaş grubu), mezgit (51-60 yaş grubu), kupes (31-40 yaş grubu) ise sadece tek bir yaş grubunda tüketilmiştir.

Araştırmaya katılan bireyler mesleklerine ilişkin yöneltilen soruya \%25,42'si serbest meslek cevabını vermişlerdir. Katılımcının en az olduğu meslek grubu ise \%8,72 ile öğretmenlik olmuştur (Şekil 3).

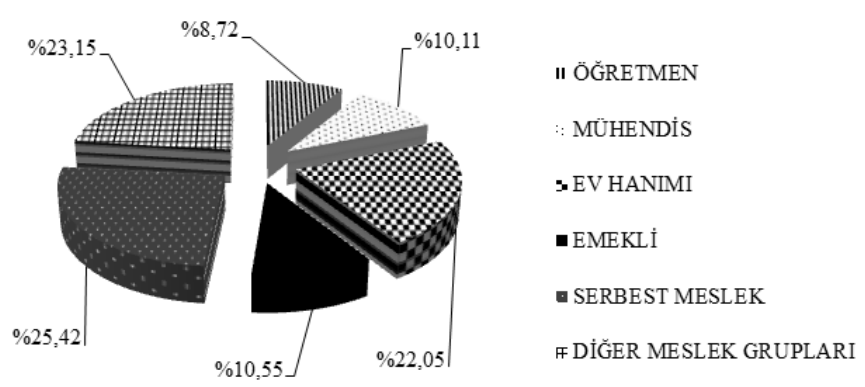

Şekil 3. Katılımcıların meslek dağılımları

Ankete katılanların eğitim durumları incelendiğinde \%34,72'sinin üniversite mezunu olduğu görülmüş, bunu $\% 31,72$ ilkokul, $\% 23,08$ lise ve $\% 10,48$ ortaokul mezunlar1 izlemiştir (Şekil 4). 


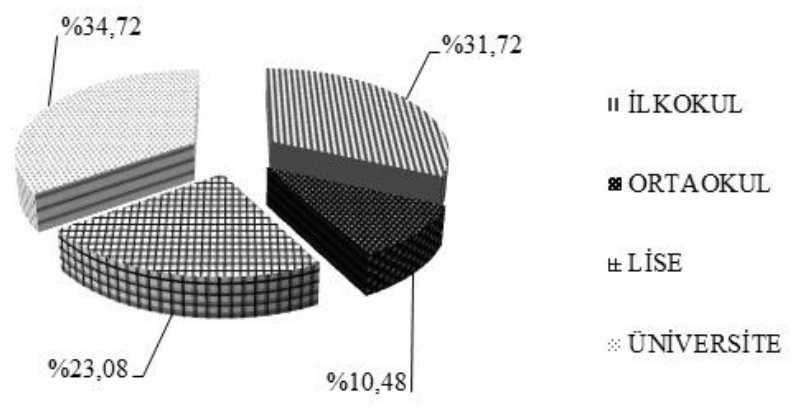

Şekil 4. Katılımcıların eğitim durumları

Katılımcıların ailede yaşayan birey sayıları incelendiğinde 4 kişilik ailelerin $\% 49,82^{\prime}$ lik bir oranla çoğunlukta olduğu tespit edilmiştir (Şekil 5).

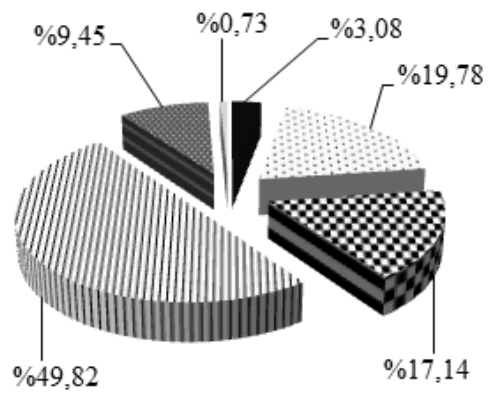

- AIILE BİREY SA YISI (1)

$\therefore$ AILE BİREY SAYISI (2)

*aíle bírey SA Yisi (3)

" AIILE BİREY SAYISI (4)

AILE BİREY SAYISI (5)

AİLE BİREY SAYISI (6)

Şekil 5. Katılımcıların ailede yaşayan kişi dağılımları

Ankete katılan bireylerin su ürünleri tüketimini önemli ölçüde etkileyen faktörlerden biri olan gelir düzeyi dikkate alındığında katılımcıların büyük çoğunluğunun 1001-2000 TL $(\% 35,09)$ ve 2001-3000 TL $(\% 34,36)$ düzeyde aylık gelire sahip oldukları tespit edilmiştir (Şekil 6).
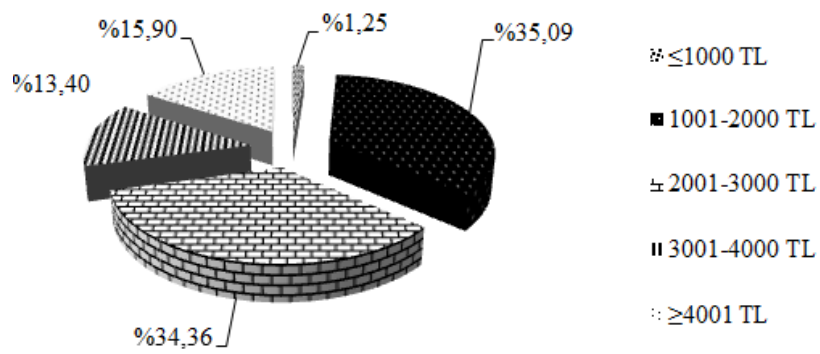

Şekil 6. Katılımcıların gelir düzeyleri 
Ankete katılan bireylerin su ürünleri tüketim sıklığının belirlenmesine yönelik soru yöneltildiğinde \%43,67'lik çoğunlukla iki haftada bir gün su ürünleri tükettikleri saptanmıştır (Şekil 7).
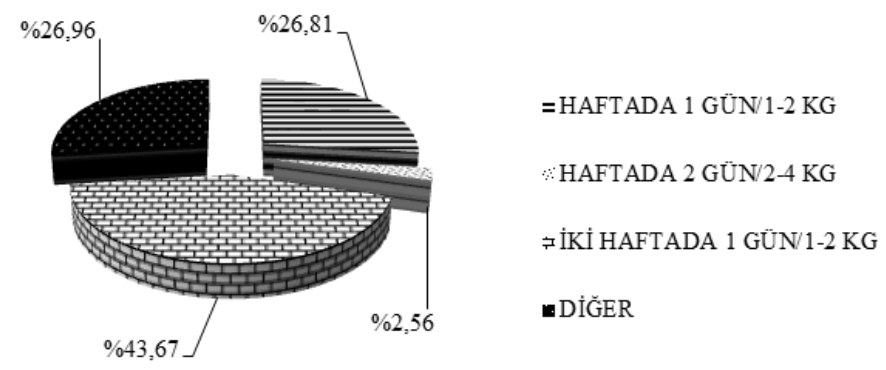

- DİĞER

Şekil 7. Katılımcıların haftada tükettiği su ürünleri miktarı dağılımları

Katılımcıların çoğunluğunun su ürünlerini tüketim şeklinin $\% 37,80$ oranla tavada pişirme yöntemi olduğu, \%8,94 ile tava+buğulamanın ise en az tercih edilen tüketim şekli olduğu belirlenmiştir (Şekil 8).

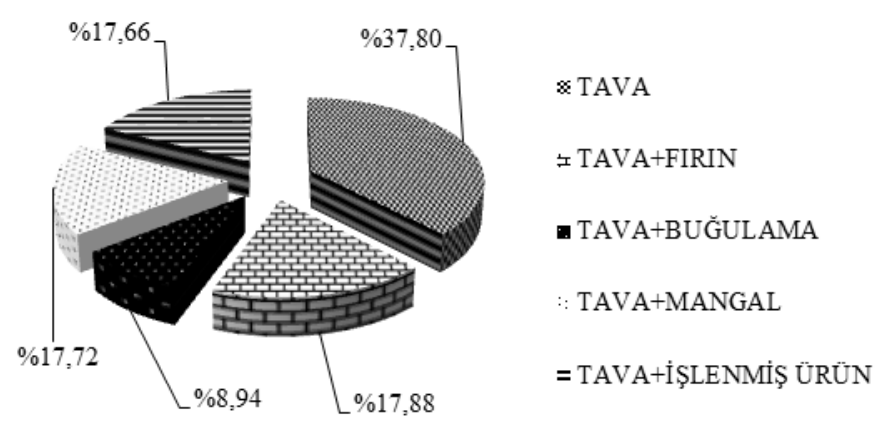

Şekil 8. Katılımcıların su ürünleri tüketim şekilleri

Çalışmada, bireylerin \%80,0'i su ürünlerini taze olarak temin ederek tükettiği tespit edilmiştir (Şekil 9).

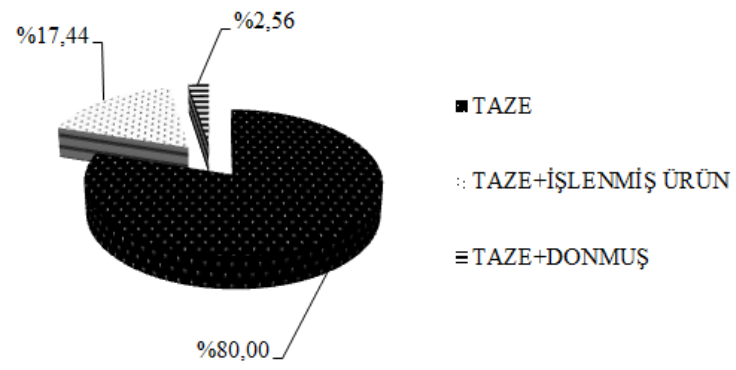

Şekil 9. Katılımcıların su ürünlerini tercih etme şekli 
Ankete katılan bireylerin \%46,96'sı ekonomik ve pratik olduğu için tavuğu tercih etmiştir (Şekil 10).

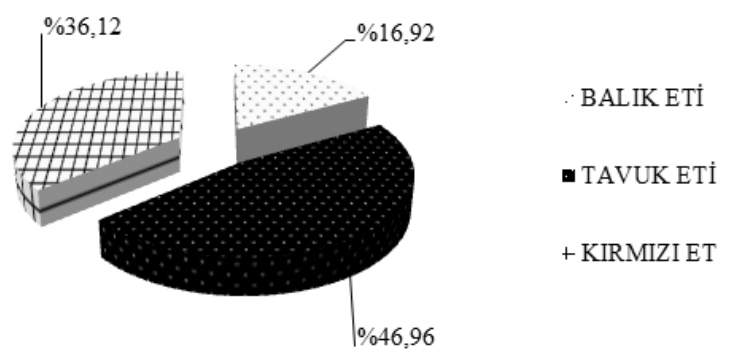

Şekil 10. Katılımcıların en çok tercih ettiği et türü

Katılımcıların su ürünlerini genellikle nereden aldıkları sorulduğunda \%41,47'si market cevabını vermiştir (Şekil 11).

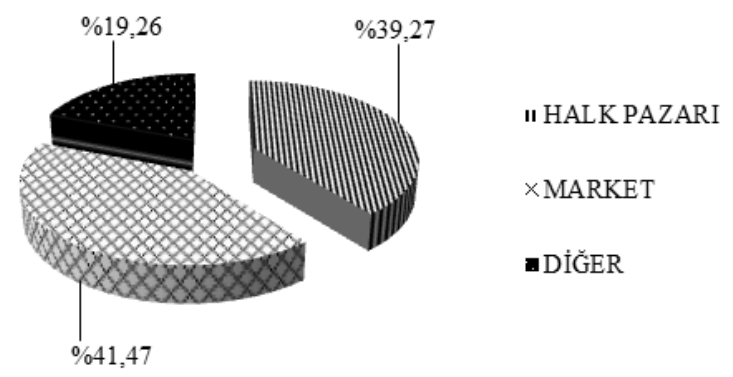

Şekil 11. Katılımcıların su ürünlerini aldıkları yerler

Ankete katılan bireyler \%72,82'lik bir oranla su ürünleri tüketiminde fiyatın önemli olduğunu belirtmişlerdir (Şekil 12).

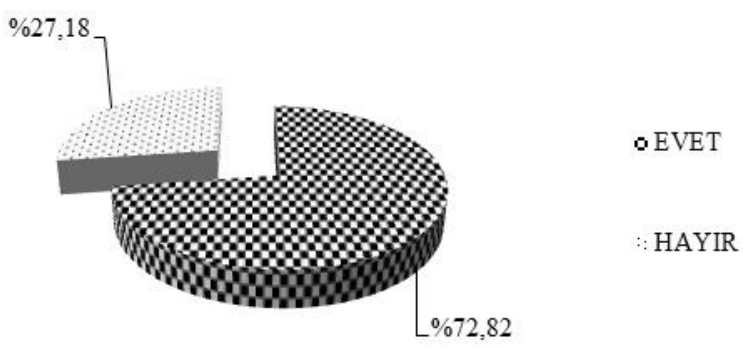

Şekil 12. Su ürünleri tüketirken fiyatın önemli olup olmadığı sorusuna verilen cevaplar 
Çalışmamızda, katılımcılara su ürünlerinin beslenmedeki önemi hakkında bilgileri olup olmadığı sorulmuş ve büyük çoğunlukla evet $(\% 96,85)$ cevabı (vitaminler açısından zengin, protein bakımından zengin, omega-3 ve omega-6 kaynă̆ı) alınmıştır (Şekil 13).

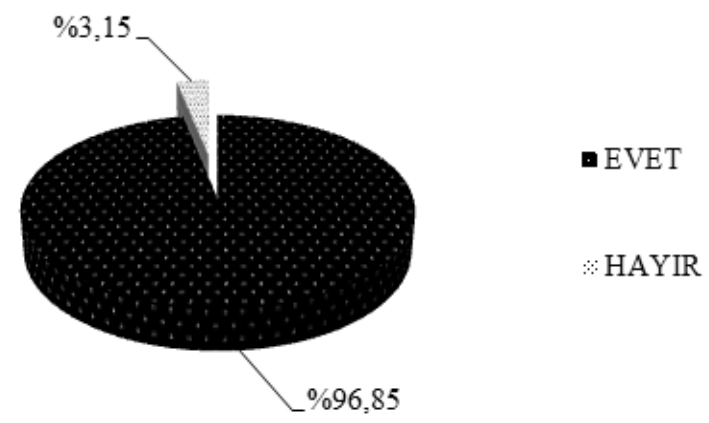

Şekil 13. "Su ürünlerinin beslenmedeki önemi hakkında bilginiz var mı?', sorusuna verilen cevaplar

Ayrıca, ankete katılan bireylere "Su ürünlerinin tercih edilmemesinin sebebi sizce nedir?" sorusu yöneltildiğinde, katılımcıların \%43,45'i tüketim alışkanlığ olmaması sebebiyle tercih etmedikleri cevabını vermişlerdir. Bunu \%35,09 ile fiyatının yüksek olması nedeniyle tercih edilmediği cevabı izlemiştir (Şekil 14).

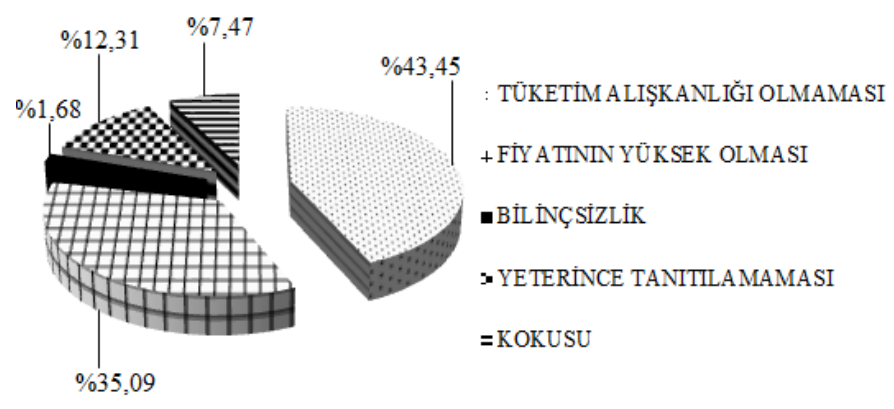

Şekil 14. "Su ürünlerinin tercih edilmemesinin sebebi sizce nedir?” sorusuna alınan cevaplar

\section{TARTIŞMA ve SONUÇ}

Tüketici tercihlerini belirlemek için anketler önemli bir bilgi toplama kaynağıdır. Bu çalışmada da Antalya ili su ürünleri tüketim alışkanlıkları anket sorularıyla belirlenmeye çalışılmıştır. Çalışma, Eylül 2014 - Ağustos 2015 tarihleri arasında tesadüfi olarak seçilen toplam 1365 birey ile gerçekleştirilmiştir.

Ankete 663'ü kadın $(\% 48,57)$ ve 702 'si erkek $(\% 51,43)$ birey katılmıştır (Şekil 1). Olgunoğlu vd. (2014)'nin Adıyaman ilinde, Balık vd. (2013)'nin Ordu ilinin Fatsa ve Aybastı ilçelerinde, Yüksel vd. (2011)'nin Tunceli ilinde, Aydın ve Karadurmuş (2013) tarafindan Giresun ve Trabzon illerinde, Çolakoğlu vd. (2006)'nin Çanakkale ilinde, Erdal ve Esengün (2008) tarafından Tokat ilinde, Orhan ve Yüksel (2010) tarafından Burdur 
ilinde yapılan bu çalışmalarda da kadın katılımcı sayısının erkek katılımcı sayısından daha az olduğu görülmüştür.

Çalışmamızda, ankete katılan bireylerin yaş dağılımlarına bakıldığında en fazla 31-40 yaşları arasında iken en az katılımcının olduğu yaş grubu 71-80 yaşlar arasında belirlenmiştir (Şekil 2). Çolakoğlu vd. (2006)'nin Çanakkale ilinde çoğunlukla 21-30 arasında (\%39,56), Aydın ve Karadurmuş (2013) tarafından yapılan çalışmada katılımcıların yaşlarının 16-76 arasında değiştiği bildirilmiştir. Adıgüzel vd. (2009) Tokat ili Almus ilçesinde yaşayan bireylerin yaşları en fazla 21-50 arasında belirlenmiştir. Bu çalışmaların bazıları çalışmamızla benzerlik göstermekle beraber, farklılık gösterenlerin çalışma sahasının farklılığından kaynaklanabileceği düşünülmektedir.

Araştırmamızda, ankete katılanların büyük çoğunluğu \%25,42 oranla serbest meslekle uğraştıklarını belirtmişlerdir (Şekil 3). Burdur ilinde yapılan çalışmada balık tüketenlerin \%47'si serbest meslekle uğraştıklarını (Orhan ve Yüksel, 2010), Çanakkale ilinde yapılan bir anket araştırmasında, katılımcıların sahip oldukları meslekleri analiz edildiğinde en fazla oran $\% 33,53$ ile memurların, bunu ise \%24,71 ile serbest meslek sahiplerinin takip ettiğini (Çolakoğlu vd., 2006), benzer konuda yapılan çalışmada, Ordu ilinin Fatsa ve Aybastı ilçelerinin her ikisinde de katılımcıların en fazla serbest meslek sahibi oldukları (Balık vd., 2013), Adıgüzel vd. (2009) tarafından yapılan çalışmada, Tokat ili Almus ilçesinde \%38,46'lık bir oranla memurların en fazla olduğu ve bunu \%24,04'lük oranla esnafların takip ettiği bildirilmiştir.

Araştırmamızda, ankete \%34,72'lik oranla en fazla üniversite mezunu katılmıştır (Şekil 4). Balık vd. (2013) tarafından yapılan anket çalışmasında, Ordu ilinin Fatsa ilçesinde yapılan çalışmada ankete katılanların \%34,7'si ortaokul, \%30'u üniversite mezunu iken, Aybastı ilçesinde ortaokul mezunlarının oranı \%31,5, üniversite mezunlarının oran 1 ise $\% 15,8$ olarak tespit edilmiştir. Tunceli ilinde yaşayan ve ankete katılan bireylerin eğitim durumları incelendiğinde katılımcıların \%55,5'inin üniversite eğitimi gördüğü, \%24,4'ünün ise lise mezunu olduğu tespit edilmiştir (Yüksel vd., 2011). Giresun ve Trabzon illerinde gerçekleştirilen anket çalışmasında katılımcıların \%45'inin lisans mezunu olduğu tespit edilmiştir (Aydın ve Karadurmuş, 2013). Adıgüzel vd. (2009) tarafindan Tokat ili Almus ilçesinde yapılan çalışmada bireylerin genel ortalamada en fazla lise $(\% 33,65)$, fakülte $(\% 20,19)$ ve ilkokul $(\% 20,19)$ mezunu oldukları belirlenmiştir. Hatırlı vd. (2004)'nin Isparta ilinde ailelerin balık tüketimlerine ilişkin yaptığı çalışmada, aile reislerinin eğitim durumları incelendiğinde \%27,54'ü ilkokul, \%10,63'ü ortaokul, \%26,57'si lise ve \%33,33'ü üniversite mezunu olduğu görülmüştür. Bu çalışmaların bazıları çalışmamızla benzerlik göstermekte olup, farklılıkların çalışma sahalarından kaynaklanabileceği düşünülmektedir.

Çalışmamızda, katılımcıların aile birey sayıları incelendiğinde \%49,82'lik bir oranla 4 kişilik aile yapısına sahip oldukları anlaşılmıştır (Şekil 5). Adıgüzel vd. (2009) tarafından Tokat ili Almus ilçesinde, Yüksel vd. (2011)'nin Tunceli ilinde yapılan bu çalışmaların bulguları çalışmamızla uyumludur.

Bu çalışmada, ankete katılan bireylerin su ürünleri tüketimini önemli ölçüde etkileyen faktörlerden biri olan gelir düzeyi incelendiğinde katılımc1ların büyük çoğunluğunu oluşturanların 1001-2000 TL (\%35,09) ve 2001-3000 TL $(\% 34,36)$ düzeyinde aylık gelire sahip oldukları tespit edilmiştir (Şekil 6). Adıyaman ilinde yaşayan ve ankete katılan bireylerin gelir düzeylerine bakıldığında asgari ücretle çalışanların oran1 \%28 iken, \%72'lik bir kesim asgari ücretin üzerinde gelir elde ettiği ifade edilmiştir (Olgunoğlu vd., 
2014). Balık vd. (2013) tarafından Ordu ili Fatsa ve Aybastı ilçelerinde sırasıyla katılımcıların gelir durumuna bakıldığında en çok \%33,7'lik oran ile 1000-2000 TL ve $\% 37,7^{\prime}$ lik oran ile 1000-2000 TL gelire sahip oldukları tespit edilmiştir. Tunceli ilinde ankete katılanların gelir düzeyleri incelendiğinde büyük çoğunluğun (\%46) 1000-2000 TL arasında aylık gelire sahip olduğu saptanmıştır (Yüksel vd., 2011). Adıgüzel vd. (2009) Tokat ili Almus ilçesinde yaptıkları çalı̧̧mada, incelenen ailelerin gelir düzeylerini en yüksek oranda $(\% 36,54) \leq 1000 \mathrm{TL}$ olarak tespit etmişlerdir. Çalışmamız ile bu çalışmaların bulguları arasında bazı benzerlikler yanında farklılıkların olduğu görülmektedir. Farklılıklar çalışmanın yapıldığı sahalardaki sosyo-ekonomik farklılıklardan kaynaklanabilir.

Antalya ilinde yapılan bu çalışmada, ankete katılan bireylerin \%43,67'si iki haftada bir gün ve $\% 26,81$ 'i ise haftada bir gün su ürünlerini tükettiklerini belirtmişlerdir (Şekil 7). Balık vd. (2013)'nin yaptığı çalışmada, Ordu ilinin Fatsa ilçesinde \%36,7'si 15 günde bir, $\% 34,8$ 'i haftada bir balık tüketildiği, Aybastı ilçesinde de haftada bir ve 15 günde bir kez balık tüketenlerin oranı Fatsa ilçesiyle benzerlik gösterdiği saptanmıştır. Orhan ve Yüksel (2010) Burdur ilinde yaşayan kişilerin balık tüketim sıklığını \%41,4'lük bir oranla haftada bir ve \%39,5'lik oranla on beş günde bir olarak belirlemiştir. Çalışmamızdaki haftada bir ve haftada iki gün tüketim sıklığı ile birlikte düşünüldüğünde genel olarak tüketim sıklığ yönüyle benzerlik göstermektedir.

Çalışmamızda, yaşa ve cinsiyete göre tüketilen su ürünlerine bakıldığında erkeklerin her yaş grubunda tüketilen balıkların hamsi ve çipura, kadınlarda ise palamut ve istavrit olduğu saptanmıştır. Balık vd. (2013) Ordu ilinin iki ilçesindeki araştırmada katılımcıların tüketimde en fazla tercih ettikleri balık türlerinin başta hamsi olmak üzere istavrit, mezgit, barbunya ve levrek olduğunu belirtmiş̧ir. Çolakoğlu vd. (2006) Çanakkale'de en çok tüketilen balıkların sırasıyla istavrit, hamsi, sardalya ve çipura olduğunu saptamıştır. Giresun ve Trabzon illerinde su ürünleri tüketim alışkanlıklarının belirlenmesine yönelik araştırmada, en çok hamsinin tercih edildiği bu balığı sırasıyla istavrit, mezgit, alabalık ve palamut balığının takip ettiği bildirilmiştir (Aydın ve Karadurmuş, 2013).

Araştırmamızda, katılımcıların su ürünlerini en fazla tüketim şekli \%37,80 ile tavada pişirme olmuştur (Şekil 8). Tunceli ilinde yaşayan bireylerin balığı tüketim şekilleri dikkate alındığında katılımcıların, balığı firında (\%42), tavada (\%37), mangalda (\%18) ve buğulama (\%3) şeklinde pişirerek tükettikleri belirlenmiştir (Yüksel vd., 2011). Giresun ve Trabzon illerinde yaşayanların su ürünlerini tüketirken pişirme şekilleri incelendiğinde kızartma, ızgara, buğulama, fırında pişirme teknikleri gibi farklı yöntemler kullandıkları, \%52,97'sinin yağda kızartma yöntemini tercih ettikleri saptanmıştır (Aydın ve Karadurmuş, 2013). Çolakoğlu vd. (2006)'nın Çanakkale ilinde yaptığı araştırmada pişirme yöntemleri arasında en çok tercih edilenin kızartma ve ızgara yöntemleri (\%8086) olduğu belirlenmiştir. Şen vd. (2008)'nın Elazığ il merkezinde, balığın daha çok kızartma yöntemiyle (\%61) tüketildiğini belirtmiştir.

Çalı̧̧mamızda, ankete katılan bireylerin \%80,0'inin su ürünlerini taze olarak tercih ettikleri belirlenmiştir (Şekil 9). Ordu ilinin Fatsa ve Aybastı ilçelerinde yapılan çalışmada ankete katılanların, Fatsa ilçesinde \%97,2'sinin, Aybastı ilçesinde ise \%98,2'sinin (Balık vd., 2013), Giresun ve Trabzon illerinde tüketicilerin \%95,14'ü (Aydın ve Karadurmuş, 2013), Çanakkale ilinde \%94-97'sinin (Çolakoğlu vd., 2006), Tokat ili Almus ilçesinde \%90,43’ünün (Adıgüzel vd., 2009) ve Burdur ilinde de katılımcıların \%99,2'sinin (Orhan 
ve Yüksel, 2010) su ürünlerini taze olarak tüketimde tercih ettiği bildirilmiştir. Bu çalışmaların sonuçları araştırmamızla uyumludur.

Araştırmamızda ankete katılan bireylerin \%16,92'lik oran ile en az balık etini tercih ettiği tespit edilmiştir (Şekil 10). Adıyaman ilinde balık eti tüketim belirlenmesi amacıyla yapılan bir araştırmada en çok tüketilen et ürünlerinin sırasıyla tavuk eti (\%56), kırmızı et (\%38) ve balık eti (\%5) olduğu tespit edilmiştir (Olgunoğlu vd., 2014). Balık vd. (2013)'nin Ordu ili Fatsa ve Aybastı ilçelerinde yaptığı bir çalışmada, katılımcıların Fatsa ilçesinde \%95,8 oranında ve Aybastı ilçesinde ise \%90,6 oranında balık eti tükettiği saptanmıştır. Tunceli ilinde yaşayanlar tarafından en fazla tüketilen et türleri sırasıyla kırmızı et (\%40), tavuk eti (\%38) ve balık eti (\%22) olarak tespit edilmiştir (Yüksel vd., 2011). Giresun ve Trabzon illerinde çalışmaya katılanların su ürünlerini birinci sırada (\%41), tavuk etini ikinci sırada (\%33), kırmızı eti ise üçüncü sırada (\%26) tükettikleri belirlenmiştir (Aydın ve Karadurmuş, 2013). Çolakoğlu vd. (2006) araştırmalarında Çanakkale ilinde beyaz etin birinci sırada $(\% 47,5)$, balık etinin ikinci sırada $(\% 29,85)$ ve kırmızı etin ise üçüncü sırada $(\% 22,05)$ tüketildiği tespit edilmiştir.

Çalışmamızda katılımcıların su ürünlerini çoğunlukla $(\% 41,47)$ marketten aldıkları saptanmıştır (Şekil 11). Balık vd. (2013) Ordu ili Fatsa ve Aybastı ilçelerinde yaptığı bir araştırmada, her iki ilçede de balığın en yüksek oranda temin edildiği yerin balık market olduğunu bildirmiştir. Tokat ilinde ailelerin balık satın alırken önceliklerinin sırasıyla sabit balık satıcıları, üretim çiftlikleri, süpermarket ve seyyar balık satıcıları olduğu tespit edilmiştir (Erdal ve Esengün, 2008). Çolakoğlu vd. (2006) Çanakkale ilinde tüketicilerin balığı en çok balık halinden almayı tercih ettiklerini belirtmiştir.

Araştırmamızda ankete katılan bireylerin \%72,82'si su ürünlerini tüketirken fiyatının önemli olduğu cevabını vermişlerdir (Şekil 12). Balık vd. (2013)'nin Ordu ilinin Fatsa ve Aybastı ilçelerindeki çalışmaları bizim çalışmamızla benzerlik göstermektedir.

Çalışmamızda, ankete katılanların su ürünlerinin beslenmedeki önemi hakkında bilgi sahibi oldukları $(\% 96,85)$ anlaşılmıştır (Şekil 13). Erdal ve Esengün (2008) Tokat ilinde yaptıkları çalışmalarında çalışmamızla benzer sonuç elde edilmiştir.

Araştırmamızda su ürünleri tüketimini olumsuz etkileyen faktörlerin başında tüketim alışkanlığının olmaması $(\% 43,45)$ katılımcılar tarafından belirtilmiştir. Bunu \%35,09 oranla fiyatının yüksek oluşu izlemiştir (Şekil 14). Şen vd. (2008) Elazığ ilinde yaptığı çalışmada katılımcıların balık fiyatlarını pahalı bulduğu belirlenmiştir. Orhan ve Yüksel (2010) tarafından yapılan çalışmada Burdur ilinde yaşayan bireylerin pişirme sırasındaki kokusundan ve aile alışkanlığı olmaması gibi sebeplerden su ürünlerini tüketmediği sonucu elde edilmiştir.

Çalışmamızda ankete katılan bireylerden alınan cevaplardan; su ürünlerinin en fazla oranla iki haftada bir tüketildiği, en fazla tercih edilen su ürünleri tüketim şeklinin tavada pişirme olduğu, en çok taze ürünlerin tercih edildiği, su ürünlerinin tüketiminde fiyatının oldukça önemli olduğu ve en çok tüketimi kısıtlayan faktörün ise tüketim alışkanlığının olmaması sonuçları elde edilmiştir. Dünya nüfusunun artmasıyla birlikte toplumların karşılaştıkları en önemli sorunlardan biri dengeli ve yeterli beslenmedir. Su ürünleri gerek besinsel kalitesi gerekse de sindiriminin kolay olması bakımından her yaş grubuna hitap eden önemli besin kaynakları içerisinde yer almaktadır. Su ürünlerinin taze ve işlenmiş olarak tüketiminin alışkanlık haline getirebilecek şekilde arttırılması bu açıdan oldukça önemlidir. Bu nedenle, insan sağlığ 1 için önemli bir besin kaynağ 1 olan su ürünlerinin tüketimi için toplum, kamu, özel kurum ve kuruluşlarca desteklenen çeşitli duyuru ve 
etkinliklerle (reklam, afiş, tanıtım etkinlikleri, kamu spotu vb.) bilgilendirilerek bilinçlendirilmeli ve su ürünleri tüketimi teşvik edilmelidir.

\section{Alıntılama}

Arslan M., İzci L. 2016. Antalya İli Su Ürünleri Tüketim Alışkanlıklarının Belirlenmesi. Eğirdir Su Ürünleri Fakültesi Dergisi. 12(1), 75-85.

\section{KAYNAKLAR}

Adıgüzel, F., Civelek, O., Sayılı, M., Büyükbay, E. O., 2009. Tokat İli Almus İlçesinde Ailelerin Balık Tüketim Durumu. Gaziosmanpaşa Üniversitesi, Ziraat Fakültesi Dergisi, 26(2), 35-43.

Aydın, M., Karadurmuş, U., 2013. Trabzon ve Giresun Bölgelerindeki Su Ürünleri Tüketim Alışkanlıkları. Karadeniz Fen Bilimleri Dergisi, 3(9), 57-71.

Atar, H. H., Alçiçek, Z., 2009. Su Ürünleri Tüketimi ve Sağlık. TAF Prev Med Bull 8 (2), 173-176.

Balık İ., Yardımcı, C., Turhan, O., 2013. Ordu İli Fatsa ve Aybastı İlçelerinde Balık Tüketim Alışkanlıklarının Karşılaştırmalı Olarak İncelenmesi. Ordu Üniversitesi Bilim ve Teknoloji Dergisi, 3(2), 18-28.

Çolakoğlu, F. A., İşmen, A., Özen, Ö., Çakır, F., Yığın, Ç., Ormancı, H. B., 2006. Çanakkale İlindeki Su Ürünleri Tüketim Davranışlarının Değerlendirilmesi. Ege Üniversitesi Su Ürünleri Dergisi, 23(1/3), 387-392.

Erdal, G., Esengün, K., 2008. Tokat İlinde Balık Tüketimini Etkileyen Faktörlerin Logit Model ile Analizi. Ege Üniversitesi Su Ürünleri Dergisi, 25(3), 203-209.

Gülyavuz, H., Ünlüsayın, M., 1999. Su Ürünleri İşleme Teknolojisi. Şahin Matbaası ISBN, $975-$ 96897-0-7, 366s.

Hatırlı, S. A., Demircan, V., Aktaş, A. R., 2004. Isparta İlinde Ailelerin Balık Tüketiminin Analizi. Süleyman Demirel Üniversitesi, İktisadi ve İdari Bilimler Fakültesi, Y. 2004, 9(1), 245-256.

Olgunoğlu, İ A., Bayhan, Y. K., Olgunoğlu, M. P., Artar, E., Ukav, İ, 2014. Adıyaman İlinde Balık Eti Tüketim Alışkanlıklarının Belirlenmesi. Gıda Teknolojileri Elektronik Dergisi, 9(1), 2125.

Orhan, H., Yüksel, O., 2010. Burdur İli Su Ürünleri Tüketimi Anket Uygulaması. Süleyman Demirel Üniversitesi, Ziraat Fakültesi Dergisi, 5 (1), 1-7.

Şen, B., Canpolat, Ö., Sevim, A. F., Sönmez, F., 2008. Elazı̆̆ İlinde Balık Eti Tüketimi. Fırat Üniversitesi Fen ve Mühendislik Bilimleri Dergisi, 20(3), 433-437.

Turan, H., Kaya, Y., Sönmez, G., 2006. Balık Etinin Besin Değeri ve İnsan Sağlığındaki Yeri. Ege Üniversitesi Su Ürünleri Dergisi, 23(1/3), 505-508.

Yüksel, F., Karaton Kuzgun N., Özer, E. İ., 2011. Tunceli İli Balık Tüketim Alışkanlığının Belirlenmesi. Karadeniz Fen Bilimleri Dergisi. 2(5), 28-36. 